\title{
UPAYA PENINGKATAN AKTIVITAS DAN HASIL BELAJAR IPS EKONOMI MELALUI PENGGUNAAN MODEL PEMBELAJARAN KOOPERATIF TIPE TGT PADA SISWA KELAS VIII B SMP NEGERI 1 RAWAJITU SELATAN LAMPUNG
}

\author{
Oleh: Edi Susanto \\ (UNIVERSITAS MEGOUPAK TULANG BAWANG LAMPUNG) \\ edi180275@gmail.com
}

\begin{abstract}
Abstrak-Upaya peningkatan aktivitas dan hasil belajar IPS ekonomi melalui penggunaan model Pembelajaran kooperatif tipe TGT pada siswa kelas VIII SMP Rawa jitu Selatan Lampung. Tujuan penelitian ini adalah untuk meningkatkan aktivitas dan hasil belajar IPS selama proses pembelajaran dengan menggunakan model pembelajaran kooperatif tipe TGT pada mata pelajaran IPS ekonomi pada siswa kelas VIII B SMP Rawajitu Selatan. Penelitian ini merupakan penelitian tindakan kelas (Classroom Action Research). Penelitian ini dilaksanakan dalam tiga siklus. Subjek penelitian ini adalah siswa kelas VIII SMP Negeri 1 Rawajitu Selatan yang berjumlah 36 orang orang. Sumber data berasal dari siswa, teman sejawat dan peneliti. Teknik pengumpulan data menggunakan observasi, test awal, turnamen, dan tes formatif. Validitas data menggunakan metode triangulasi teknik dan sumber. Analisis data yang digunakan dengan analisis kualitatif dan kuantitatif. Hasilnya menunjukan bahwa penggunaan model pembelajaran Kooperatif tipe TGT dapat meningkatkan aktivitas dan hasil belajar IPS ekonomi pada siswa kelas VIII B.
\end{abstract}

Kata Kunci: Pembelajaran Kooperatif, Tipe TGT, IPS Ekonomi

\begin{abstract}
The improving activity and result social studies learning through using cooperative model TGT type in VIII B grade student of Junior High school Rawajitu Selatan The purpose of this research was to improve the social studies learning through cooperative model TGT type in VIII B grade. This research uses classroom action research techniques. The research was conducted in three cycles. Subject of this study is the VIII B grade student of Junior Highh school Rawajitu Selatan. Which has 36 students. Data sources come from teachers, students and researchers. Data colection techniques using observation, pretest, tournament and formatif test.The validity of data using triangulation methods techniques and other sources. Analysis of the data used by the qualitative and quantitative analysis. The result showed that the use of cooperative learning TGT type can improve the social studies learning.
\end{abstract}

Keyword: Cooperative Learning, TGT, Social Studies 


\section{PENDAHULUAN}

Pendidikan pada dasarnya adalah usaha sadar untuk menumbuhkembangkan potensi sumberdaya manusia yaitu peserta didik dengan cara mendorong dan mempasilitasi kegiatan belajar mereka. Pendidikan sengaja dirancang untuk mencapai tujuan yang telah ditetapkan. Pendidkan mempunyai peranan yang sangat penting dalam kehidupan manusia, karena dengan adanya pendidikan akan terbentuk manusia yang trampil dan berkualitas. Peningkatan kualitas sumber daya manusia (SDM) merupakan suatu keharusan bagi bangsa Indonesia sebagai negara yang sedang berkembang, karena pada era globalisasi menuntut kesiapan setiap bangsa untuk saling bersaing secara bebas. Oleh karena itu, sudah semestinya pembangunan sektor pendidikan menjadi prioritas utama yang harus dilakukan oleh pemerintah (Basrowi, 2008:1)

Sebagaimana diketahui kualitas pendidikan akan sangat menetukan mutu kehidupan bangsa upaya peningkatan kualitas pendidikan terus menerus harus dilakukan. Pendidikan yang baik adalah pendidikan yang berdaya guna dan mampu membentuk manusia yang beradab dan berkeahlian. Pendidikan dapat dikatakan berhasil apabila menghasilkan lulusan yang berkualitas. Salah satu upaya untuk meningkatkan sumber daya manusia (pesert didik) adalah proses pembelajaran di sekolah.

Keberhasilan penyelenggaraan pendidikan banyak ditentukan oleh proses belajar mengajar yang ditangani langsung oleh para guru. Pembelajaran yang berkualitas memerlukan pengembangan model pembelajaran yang tepat, sehingga menjadi lebih efektif dan efisien.

Tugas guru bukan semata-mata mengajar tetapi kepada membelajarkan siswa, khususnya dalam mengajar IPS guru harus mampu menggunakan model pembelajaran yang efektif dan efisien sehingga siswa aktif dalam belajar,tidak hanya sebagai pendengar. Dalam pembelajaran IPS siswa membutuhkan pemahaman dan mampu menerapkan dalam dunia nyata. Salah satu cara yang dapat mengkondisikan lingkungan belajar yang aktif serta mengurangi kejenuhan siswa adalah melalui model pembelajaran kooperatif tipe TGT.

Dalam pembelajaran kooperatif tipe TGT ini siswa ditempatkan dalam kelompok belajar yang heterogen. Kemudian dalam kelompok tersebut siswa dapat saling berdiskusi dan berkerja sama untuk memahami materi dengan baik. Pembelajaran kooperatif tipe TGT akan memberikan peluang besar bagi siswa yang aktivitas belajarnya rendah karena siswa tersebut dapat bertanya dengan teman sekelompoknya tentang materi yang belum dimengertinya. Hasil 
belajar dalam model pembelajaran kooperatif tipe $T G T$ ini diambil dari hasil turnamen ditiap akhir siklus dimana siswa dari berbagai kelompok heterogen ditempatkan dalam bentuk kelompok homogen dalam hal tingkat kepintaran.

Tiap kelompok homogen mendapat soal dengan bobot yang berbeda sesuai dengan tingkat kepintarannya. Turnamen akan memacu semangat siswa untuk menjadikan kelompoknya sebagai kelompok yang terbaik. Sehingga hasil belajar siswa dapat lebih baik karena tiap siswa memperoleh hasil belajar sesuai dengan kemampunnya

Belajar merupakan proses perubahan tingkah laku individu sebagai hasil dari pengalamannya dalam berinteraksi dengan lingkungan.Sedangkan pembelajaran merupakan upaya menciptakan kondisi belajar antara guru dan siswa agar tercapai tujuan pembelajaran. Dalam pembelajran guru harus mengaktifkan siswa dan menciptakan kondisi belajar yang menyenangkan. Pembelajaran merupakan bantuan yang diberikan pendidik agar dapat terjadi proses pemerolehan ilmu dan pengetahuan, penguasaan konsep pembelajaran, dan pembentukan sikap pada pesert didik agar dapat belajar dengan baik.

Dalam pembelajaran IPS siswa membutuhkan pemahaman dan mampu menerapkan dalam dunia nyata.Pembelajaran IPS merupakan upaya menerapkan teori, konsep, prinsip ilmu sosial untuk menelaah pengalaman, gejala, masalah sosial yang nyata terjadi di masyarakat". Wahab, dkk, 2009:1-9). Pembelajaran IPS melatih ketrampilan para siswa baik ketrampilan fisik maupun ketrampilan berpikirnya dalam mengkaji dan mencari pemecahan dari masalah sosial yang dialaminya.

Pembelajaran IPS di Indonesia diarahkan pada upaya mempelajari kehidupan sosial yang didasarkan bahan kajian geografi, ekonomi,m sosiologi, antropologi, tata negara dan sejarah. Tujuannya agar siswa mampu mengembangkan pengetahuan dan ketrampilan dasar yang berguna bagi dirinya dalam kehidupan sehari-hari (Sapriya, 2011;113).

Berdasarkan pendapat di atas disimpulkan bahwa pembelajaran IPS merupakan pembelajaran yang membutuhkan pemahaman,keatifan serta penerapan dalam kehidupan siswa yang bertujuan untuk memahmi gejala, kondisi dan masalah di masyarakat. dalam pembeljaran IPS guru membutuhkan model pembelajaran yang dapat mengaktifkan, menyenangkan dan memberi pemahaman bagi siswa. kegiatan ekonomi dalam memanfaatkan sumber dayaalam memiliki lima sub bab yaiut jenis kubutuhan hidup, kegiatan ekonomi penduduk, potensi daerah, pemanfaatan potensi daerah dalam kegiatan ekonomi dan tempat 
kegiatan ekonomi. Koperasi memeliki delapan sub bab yaitu pengertian koperasi, manfaat dan tujuan koperasi, prinsip koperasi,hak dan kewajiban anggota koperasi, organisasi koperasi, lambang koperasi, modal koperasi dan jenis koperasi. pengunaan model pembelajaran kooperatif TGT sangat tepat digunakan dalam pembelajaran IPS karna siswa aktif belajar, aktif bertanya, menyenangkan karna belajar sambil bermain, berusaha memahami mati pembelajaran sehingga dapar menerapkan di kehidupan sehari-hari serta pembelajaran IPS dapat meningkat. peningkatan pembelajaran IPS merupakan peningkatnya proses pembelajran dan hasil belajar siswa tentang ilmu penegtahuan yang bertujuan untuk memahami gejala, kondisi dan masalah sosial di masyarakat.

Model pembelajaran adalah rencana untuk pembentukan kurikulum, merancang bahan-bahan pengajarn dan membimbing pengajaran di kelas. model pembelajran kooperatif adalah model pembelajaran dimana siswa belajar dan bekerja dalam kelompok kecilyang berangotakan 4-6 orang dengan struktur kelompok heterogen. model pembenlajaran kooperatif mengutakmakan kerja sama dlama menyelesaikan permasalahan untuk menerapkan pengetahuan dan keterampilan dalam rangka mencapai tujuan pembelajaran.
Menurut Slavin dalam Etin dan Raharjo (2007:4) mengatakan bahwa pembelajaran kooperatif (cooperative learning) adalah suatu model pembelajaran dimana siswa belajar dan berkerja dalam kelompokkelompok kecil secara kolaboratif yang anggotanya terdiri dari 4 sampai 6 orang dengan anggota kelompoknya yang bersipat heterogen. Ada banyak sekali jenis atau tipe pembelajaran kooperatif

$$
\text { Wartono dkk }
$$
menyatakan bahwa TGT adalah salah satu tipe pemblajran kooperatip yang menempatkan siswa dalam kelompok - kelompok belajar berangotakan 5-6 orang siswa yang memiliki kemampuan, jenis kelamin, dan suku bangsa atau ras yang berbeda". (hal. 83). Sedangkan menurut Steve Pearson dalam Slavin (1995:85) menyatakan TGT adalah salah satu teknik terbaik yang digunakan oleh guru untuk suatu kompetisi yang positif atau bersifat membangun.Siswa menyadari bahwa kompetisi adalah sesuatu yang mereka hadapi sejak awal. Untuk itu, TGT memberi mereka strategi untuk menyelesaikan tugas atau masalah, setiap kelompok dapat meminta bantuan/menerima saran dari kelompok mereka. Setiap anggota kelompok harus yakinn atau percaya pada kelompok mereka dalam menyelesaikan tugas di turnamen dari beberapa pendapat dapat disimpulkan bahwa model pembelajran kooperatif tipe TGT 
adalah model pembelajaran yang mengkondisikan sisiwa dalam bentuk kelompok akademik dan mengunakan game turnamen dimana para siswa berlomba sebagai wakil tim dengan tin yang lain.

Slavin berpendapat bahwa "TGT terdiri dari lima tahapan yaitu tahap penyajian kelas (class Presentastion). belajar dalam kelompok (teams). permaina (games). pertandingan (tournament). dan penghargaan kelompok (team recognition)". (Rusman, 2012 ; 225). seperti yang diungkapkan oleh salvin maka model pembelajaran tipe TGT memiliki ciri sebagai berikut : a) penyajian kelas. b) siswa bekerja dalam kelompok kecil c) siswa bermain dalam tournament d) siswa mendapat penghargaan kelompok.

Perumusan masalah oleh peneliti yaitu Apakah penggunaan model pembelajaran kooferatif tipe Teams games Tournament (TGT) dapat meningkatkan aktifitas belajar IPS ekonomi pada siswa kelas VIII SMP Rawajitu Selatan tahun Pelajaran 2015/2016?. Tujuan penelitian ini adalah untuk meningkatkan aktivitas dan hasil belajar siswa selama proses pembelajaran dengan menggunakan Teams Games Tournamen (TGT) pada mata pelajaran IPS siswa kelas VIII SMP 1 Rawajitu Selatan tahun Pelajaran 2015/2016.

\section{METODE PENELITIAN}

Penelitian ini merupakan Penelitian Tindakan kelas (PTK) yang dilaksanakan tiga siklus, dari setiap siklus terditi dari perencanaan,pelaksanaan,observasi dan refleksi. Penelitian tindakan kelas (PTK) dilaksanakan di kelas VIII SMP Rawajitu Selatan .Penelitian ini dilakukan pada Semester II tahun ajaran 2015/2016. Subjek penelitian ini adalah siswa kelas VIII yang berjumlah 36 siswa.sedangkan objek penelitian adalah pembelajaran IPS ekonomi. Faktor yang diteliti dalam penelitian ini adalah:

1. Aktivitas belajar adalah setiap kegiatan yang dilakukan oleh siswa selama proses pembelajaran berlangsung,

2. Hasil belajar siswa yang ditunjukan oleh nilai rata-rata kelas yang diperoleh siswa dari tes formatif setelah pertandingan antar kelompok/turnamen di setiap akhir siklus setelah kegiatan pembelajaran,

3. Kinerja guru dalam kegiatan pembelajaran.

Penelitian ini adalah penelitian tindakan kelas (PTK) yang dilaksanakan pada siklus 1 , siklus II, dan siklus III, dengan tahapan secara umum sebagai berikut. Kemmis \& Mc Taggart (1982) dalam Basrowi \& Suwandi (2008: 26) : 1. Perencanaan, 
2. Pelaksanaan, 3. Pengamatan, 4. Refleksi.

Tahapan-tahapan yang akan dilakukan dalam penelitian ini meliputi dua tahap kegiatan yaitu tahap prapenelitian dan tahap pelaksanaan kegiatan, 1. Tahap prapenelitian, a. Memberikan tes awal untuk mengetahui kemampuan akademik siswa, yang skornya akan dijadikan skor awal dan selanjutnya akan digunakan untuk sebagai pedoman pembagian kelompok, b. Membagi siswa ke dalam kelompokkelompok kecil berdasarkan hasil tes awal, c. menjelaskan kepada siswa tentang langkah-langkah pembelajaran tipe $T G T$ yang akan dilaksanakan, ketentuan-ketentuan sebagai berikut: 1. Anggota kelompok yang pandai dituntut untuk dapat memberitahu temannya yang tidak mengerti atau sulit untuk menerima materi, sedangkan anggota kelompok yang masih tidak mengerti hendaknya bertanya kepada temannya yang mengerti, 2. Pada saat pembelajaran, setiap anggota kelompok duduk membentuk lingkaran atau saling berhadaphadapan, 3. Setiap siswa harus memperhatikan baik-baik pada saat guru menyampaikan materi pelajaran, 4. Setiap anggota kelompok harus berani menyampaikan pendapat, gagasan atau pertanyaan serta mendengarkan dengan baik penjelasan temannya, 5 . Seluruh anggota kelompok harus mengusahakan agar terjadi diskusi aktif. 2. Tahap pelaksanaan penelitian yang terdiri dari beberapa tahap, yaitu: (a) perencanaan,(b) pelaksanaan, (c) pengamatan, (d) Refleksi yang akan membentuk siklus.

Data yang digunakan dalam penelitian ini adalah data kualitatif dan kuantitatif. Data kualitatif merupakan data hasil observasi yang terjadi dalam kelas pada siklus I, II, III, Data kuantitatif diambil dari data hasil belajar siswa,yaitu data yang diperoleh dari hasil tes individu/tes formatif setelah diadakan kegiatan turnamen disetiap siklus (Sugiyono, 2009: 246). indikator keberhasilan dalam penelitian ini $85 \%$ prosedur mengunakan model pembelajaran tipe kooperatif TGT yang di laksanakan oleh guru yang diamati pada saat pembelajaran dan dihitung melalui akumulasi skor - skor dari deskripsi yang menunjukan pengunaan model pembelajaran kooperatif tipe TGT oleh guru, dan $85 \%$ kegiatan dan respon siswa pada saat pembelajran IPS melalui proses pembelajaran model TGT yang diamati pada saat pembelajaran berlangsung dan dihitung melalui akumulasi skor - skor dari diskripsi yang menunjukan keterlaksanaan pembelajaran masing masing langkah mengunakan model pembelajaran kooperatif tipe TGT oleh siswa, serta $80 \%$ hasil belajar IPS materi aktifitas ekonomi yang berkaitan dengan SDA dan potensi lain didaerah serta mengenal 
pentingnya koperasi dan meningkatkan kesejah teraan masyarakat yang dihitung dari hasil tes / evaluasi semua siswa dalam kelas pada mata pelajaran IPS yang memperoleh nilai diatas KKM atau mencapai batas tuntas sebesar $70 \%$. Instrumen penelitian yang digunakan adalah perangkat tes, lembar observasi, dan perangkat pertandingan (soal pertandingan, lembar jawaban, aturan permainan, kartu poin/kemenangan dan lembar poin TGT). Lembar observasi yang digunakan adalah lembar observasi aktivitas siswa yaitu meliputi perilku

\section{HASIL DAN PEMBAHASAN.}

Sebelum penelitian ini dilaksanakan peneliti membuat Perencanaan dengan meminta ijin sekolah, menentukan observer, menyusun RPP, menyiapkan model TGT beserta langkahnya, menyiapkan sarana dan prasarana, menyiapkan instrumen dan menyusun tim kerja dan tim tournaments. Kemudian dalam melaksanakan penelitian, kegiatan pembelajaran yang dilakukan setiap pertemuan dalam penelitian tindakan kegiatan kelas ini meliputi kegiatan awal, inti dan akhir. Kegiatan awal pembelajaran diawali salam, berdoa bersama, mengabsen kehadiran siswa, apersepsi untuk menjembatani materi yang akan dipelajri dengan pengetahuan awal siswa yaitu siswa menyanyikan lagu "sesuai materi", kemudian guru menyampaikan siswa yang relevan dengan kegiatan pembelajaran. Instrumrn penelitian berupa perangkat tes yang diberikan di akhir setiap siklus dengan tujuan untuk mengukur hasil belajar IPS ekonomi siswa terlebih dahulu dilakukan uji instrumen tes, tujuannya adalah untuk mengetahui Validitas,reliabilitas, tingkat kesukaran, dan daya pembeda soal. Uji instrumen tes dilaksanakan di kelas VIII A SMPN 1 Rawajitu Selatan. Kemudian tes diberikan pada kelas penelitian yaitu kelas VIII B SMPN 1 Rawajitu Selatan.

tujuan pembelajaran yang harus dicapai.

Penerapan model pembelajaran kooperatif tipe TGT dilaksanakan pada saat kegiatan inti yang dibagi kedalam tiga tahap yaitu eksplorasi, elaborasi dan konfirmasi. Pada kegiatan ini guru melaksanakan lima tahapan dari model pembelajaran kooperatif tipe $T G T$. Pembelajaran dimulai penyajian kelas. Peneliti menjelaskan materi pelajaran serta bertanya jawab dengan siswa dengan menampilkan berbagai gambar menggunakan LCD proyektor. Kedua pelaksanaan kerja kelompok (teams) yaitu guru membagi siswa menjadi lima kelompok 9 teams) secara heterogen untuk bekerja kelompok mengerjakan LKS, sebelum guru membagikan LKS dan menjelaskan cara pengisiannya. Setelah masingmasing kelompok selesai 
mengerjakan LKS setiap perwakilan kelompok maju membacakan hasilnya kemudian dibahas dan disimpulkan bersama guru. Ketiga pelaksanaan permainan (games) yaitu siswa memasuki meja tournamen sesuai pembagian guru. Setelah masing-masing siswa masuk dalam meja tournamen guru menjelaskan aturan permainan (games). Siswa mulai melaksanakan permainan (games) dengan cara siswa yang pertama meja tournamen 1 maju untuk mengocok kartu nomor kemudian mencocokkan dengan lembar soal TGT untuk menjawab soal sesuai nomor soal yang didapat. Sampai siswa yang terkahir pada meja tournamen 5. Keempat Pelaksanaan Pertandingan (Tournamen). Sebelum pertandingan dilaksanakan guru menjelaskan aturan pertandingan dan penskorannya. Bagi siswa yang dapat menjawab soal dengan benar saat mengocok kartu nomor akan mendapat skor 10, namun apabila tidak dapat menjawabnya atau jawabannya salah maka skornya 0 . Kemudian akan dilempar kepada penantang 1, 2, 3 atau 4. Bagi penantang yang dapat menjawab soal lemparan dengan benar akan mendapat skor 20 namun apabila tidak ada satupun penantang yang dapat menjawab dengan maka kartu soal masuk box. Setelah selesai sampai tournamen 5 siswa kembali kekelompok (teams) asal dan menghitung skor masing-masing yang didapat dan dicatat dalam lembar penilaian teams dan kelima pelaksanaan rekognisi/Penghargaan kelompok guru mengumumkan juara games akademik dengan skor tertinggi dan memberi penghargaan berupa hadiah. Kegiatan pembelajaran yang terakhir adalah kegiatan akhir yang terdiri dari memberi kesempatan siswa untuk bertanya dan menulis materi, melaksanakan evaluasi, berdoa dan memberi salam.

Kegiatan obeservasi bertujuan untuk mengevaluasi rangkaian pembelajaran yang dilaksanakan. Berdasarkan perencanaan hal-hal yang diamati adalah kegiatan guru, siswa dan hasil belajar IPS siswa. Berikut penejelasan hasil observasi pada siklus I, II dan III pembelajaran IPS melalui model pembelajaran kooperatif tipe TGT.

Tabel 1. Aktifitas Guru dan Siswa Dalam Penggunaan Model Pembelajaran Kooperatif tipe TGT

\begin{tabular}{|c|c|c|c|c|}
\hline Kegiatan & $\begin{array}{c}\text { Siklus } \\
\text { I } \\
(\boldsymbol{\%})\end{array}$ & $\begin{array}{c}\text { Siklus } \\
\text { II } \\
(\boldsymbol{\%})\end{array}$ & $\begin{array}{c}\text { Siklus } \\
\text { III } \\
(\boldsymbol{\%})\end{array}$ & Rata-rata \\
\hline Guru & 61,4 & 72,9 & 86,4 & 72,6 \\
\hline Siswa & 67,6 & 74,7 & 81,4 & 74,6 \\
\hline
\end{tabular}

Sumber: Diolah dari hasil observasi aktivitas guru dan siswa 
Berdasarkan tabel I aktivitas guru dalam melaksanakan pembelajaran melalui model pembelajaran kooperatif tipe TGT mengalami peningkatan dalam setiap siklus. Pada Siklus I 61,4\% meningkat pada Siklus II $72,9 \%$ sehingga memperoleh rata-rata $72,6 \%$.

Aktivitas siswa dalam melaksanakan pembelajaran IPS melalui model pembelajaran kooperatif tipe TGT mengalami peningkatan dalam setiap siklus. Pada siklus I 67,6\% meningkat pada siklus II $72,9 \%$ dan meningkat lagi pada siklus ke II $81,4 \%$, sehingga memperoleh rata-rata $72,6 \%$. Peningkatan pembelajaran oleh guru dan siswa dapat mencapai indikator yang direncanakan yaitu $74,6 \%$

Tabel 2. Hasil Belajar Siswa Pada Siklus I, II dan III

\begin{tabular}{|c|c|c|c|}
\hline Siklus & Nilai Rata-rata & $\begin{array}{c}\text { Ketuntasan } \\
(\mathbf{\%})\end{array}$ & Keterangan \\
\hline Siklus I & 68,8 & 67,65 & meningkat \\
\hline Siklus II & 71,5 & 78,79 & meningkat \\
\hline Siklus III & 72,9 & 85,29 & meningkat \\
\hline
\end{tabular}

Sumber: Diolah dari hasil belajar siswa

Berdasarkan tabel 2 diperoleh data bahwa rata-rata kelas dan ketuntasan siswa pada siklus I, II dan III mengalami peningkatan. Pada Siklus I rata-rata kelas 69 meningkat pada Siklus II 72, meningkat lagi pada siklus III 73. Ketuntasan belajar pada siklus I67,65 \% meningkat pada siklus II 78,79 \%, siklus III 85,29\%. Peningkatan tersebut dapat mencapai indikator $77 \%$. Sehingga penerapan model pembelajaran kooperatif tipe TGT dapat meningkatkan pembelajaran IPS pada siswa kelas VII SMP 1 Rawa Jitu Selatan.

\section{SIMPULAN DAN SARAN}

Penggunaan model pembelajaran koopertif tipe TGT dapat meningkatkan pembelajaran IPS bagi siswa kelas VIII SMP 1
Rawajitu Selatan Tahun Ajaran 2015/2016. Peningkatan Pembelajaran IPS ini ditunjukkan dengan adanya peningkatan pembelajaran IPS serta aktivitas siswa dan guru dalam proses pembelajaran pada siklus I, II dan III. Pada siklus I aktivitas guru mendapat skor rata-rata 61,4 meningkat pada siklus II menjadi 72,9 dan pada siklus III menjadi 86,4. Sehingga memperoleh rata-rata 72,6

Aktivitas siswa pada siklus I mendapat skor rata-rata $67,6 \%$ ,meningkat pada siklus II menjadi $74,7 \%$, siklus III 81,4 dengan ratarata $75 \%$. Persentase ketuntasan belajar siswa pada siklus I sebesar $67 \%$ meningkat pada siklus II $85 \%$, siklus III $79 \%$. Nilai rata-rata kelas 
pada siklus I mencapai 69, siklus II 72 dan siklus III 73.

Berdasarkan hasil tindakan yang dilaksanakan, disampaikan saran sebagai berikut : (1) guru pada saat pembelajaran IPS kelas IV sebaiknya menggunakan model pembelajaran kooperatif tipe TGT agar dapat meningkatkan pembelajaran IPS. (2) siswa dalam pembelajaran IPS melalui model pembelajaran kooperatif tipe TGT sebaiknya semua siswa ikut terlibat pada setiap langkah pembelajaran, harus lebih aktif bertanyadan mengemukakan pendapatnya. penelitian tetap menggunakan model pembelajaran kooperatif tipe TGT sebagai salah satu model penunjang pembelajaran khususnya mata pelajaran IPS dan senantiasa memperbaiki hasil penelitian supaya diperoleh hasil penelitian yang lebih baik dan memperkenalkan kepada para pendidik lainnya. (4) sekolah sebaiknya menghimbau semua guru yang ada disekolah supaya menggunakan model pembelajaran kooperatif tipe TGT sebagai alternatif penunjang pembelajaran saat mengajar IPS.

\section{DAFTAR PUSTAKA}

Basrowi dan Suwandi. 2008. Prosedur Penelitian Tindakan Kelas. Bogor: Ghalia Indonesia Rusman. 2012. Model-model pembelajaran mengembangkan profesionalisme guru. Depok : Rajagrafindo Persada.

Sapriya. 2011. Pendidikan IPS konsep dan pembelajaran. Bandung: PT Remaja Rosdakarya.

Slameto. 2003. Belajar dan FaktorFaktor yang Mempengaruhinya. Jakarta: Rineka Cipta

Slavin, Robert E. 1995. Cooperative learning Theory, Research and Practice. Allyn Bacon: Boston

Slavin, Scmariani, Frank Lyman dan Spencer Kagan. Http:)//scmarianiunnes.blogspot.com/2008/11/m eningkatkan-efektifitasperkuliahan.html.

Solihatin, Etin dan Raharjo. 2007. Cooperative Learning: Analisis Pembelajaran IPS. Jakarta: Bumi Akasara.

Wahab, A.A.dkk. 2009. Konsep Dasar IPS. Jakarta: Universitas Terbuka 